\title{
PENGARUH KINERJA LINGKUNGAN, PENGUNGKAPAN LINGKUNGAN, DAN PROFITABILITAS TERHADAP TINGKAT PENGEMBALIAN SAHAM: STUDI EMPIRIS DI BURSA EFEK INDONESIA
}

\author{
Hidayah Wiweko dan Suci Dhea Friscila \\ Fakultas Ekonomi dan Bisnis, Universitas Lampung \\ Email korespondensi: hidayah.wiweko@feb.unila.ac.id
}

\begin{abstract}
ABSTRAK
Tujuan dilakukan penelitian ini adalah untuk mengetahui pengaruh kinerja lingkungan, pengungkapan lingkungan dan profitabilitas terhadap return saham. Variabel independen dalam penelitian ini adalah kinerja lingkungan, pengungkapan lingkungan dan profitabilitas. Variabel dependen dalam penelitian ini adalah return saham. Populasi dalam penelitian ini adalah sektor manufaktur yang memperoleh peringkat PROPER dan terdaftar di Bursa Efek Indonesia (BEI) tahun 2015-2018 sebanyak 42 perusahaan. Sampel dalam penelitian ini diambil dengan menggunakan metode purposive sampling. Analisis data menggunakan statistik deskriptif, uji asumsi klasik, analisis regresi berganda dan pengujian hipotesis. Hasil penelitian ini menunjukkan bahwa variabel kinerja lingkungan, pengungkapan lingkungan dan profitabilitas berpengaruh signifikan terhadap return saham.
\end{abstract}

Kata Kunci: return saham, kinerja lingkungan, pengungkapan lingkungan, profitabilitas

\begin{abstract}
The purpose of this research is to determine the effect of environmental performance, environmental disclosure and profitability on stock return. The independent variables in this study are environmental performance, environmental disclosure, profitability. The dependent variable in this study is stock return. The population in this study is the manufacturing sector which received a PROPER rating and was listed on the Indonesia Stock Exchange (IDX) in 2015-2018 as many as 42 companies. The sample in this study was taken using a purposive sampling method. Data analysis uses descriptive statistics, classic assumption tests, multiple regression analysis and hypothesis testing. The results of this study indicate that environmental performance, environmental disclosure and profitability variables have a significant effect on stock returns.
\end{abstract}

Keywords: stock return, environmental performance, environmental disclosure, profitability 


\section{PENDAHULUAN}

Saat ini isu permasalahan lingkungan hidup telah menjadi topik penting dalam ekonomi global dan menjadi sorotan masyarakat dunia yang menarik untuk dibahas. Hal ini dapat dilihat dari semakin banyaknya organisasi-organisasi seperti WALHI (Wahana Lingkungan Hidup Indonesia), Greenpeace, dan IUCN (International Union for concervation of nature). Peraturan-peraturan mengenai lingkungan hidup juga saat ini semakin berkembang dengan tujuan dapat terciptanya perlindungan lingkungan hidup dan pembangunan yang berkelanjutan (Octavia, 2012). Perubahan lingkungan yang sangat dinamis, baik yang disebabkan oleh kegiatan eksternal maupun internal perusahaan, memaksa para pelaku bisnis untuk tidak hanya meningkatkan laba dan kinerjanya, tetapi juga harus peduli terhadap masalah sosial.

Kegiatan sebuah perusahaan tidak terlepas dari lingkungannya sebab lingkungan memberikan andil dan kontribusi juga bagi perusahaan. Aktivitas lingkungan yang berkualitas perlu juga diterapkan agar dapat meningkatkan kinerja lingkungan perusahaan, namun perusahaan seringkali mengabaikan kaitan antara lingkungan dan kegiatan perusahaan. Terjadinya pencemaran lingkungan akibat dari kurangnya perhatian perusahaan terhadap dampak lingkungan yang ditimbulkan oleh aktivitas industri baik ketika memperoleh bahan baku, proses produksi, maupun hasil produksi.

Pencemaran lingkungan di Indonesia terjadi akibat dari dampak pengelolaan lingkungan yang tidak sesuai dengan yang telah ditetapkan oleh pemerintah. Beberapa perusahaan masih belum memikirkan mengenai dampak-dampak sosial yang akan terjadi akibat dari aktivitas industri yang menggunakan teknologi canggih serta bahan-bahan kimia berbahaya. Perusahaan hanya memikirkan bagaimana cara agar dapat memperoleh laba yang maksimal dan memperoleh asupan modal tanpa memperhatikan kelestarian lingkungan disekitar usaha bisnisnya. Hal ini sesuai dengan pendapat Hastawati \& Sarsiti (2016) bahwa prinsip maksimalisasi laba untuk mencari keuntungan maksimal banyak dilanggar perusahaan, seperti rendahnya manajemen lingkungan, kinerja lingkungan, dan rendahnya akan minat terhadap konservasi lingkungan.
Sejak tahun 2002, Kementerian Lingkungan Hidup (KLH) membentuk program yang disebut Program Penilaian Peringkat Kinerja Perusahaan yang selanjutnya disebut (PROPER) sebagai bentuk penataan lingkungan hidup perusahaan-perusahaan di Indonesia. Perusahaan dianggap berhasil dalam kinerja lingkungannya diukur dengan prestasi yang diraih oleh perusahaan dalam mengikuti program PROPER. Hal ini dilakukan untuk memotivasi perusahaan agar terus semakin baik dan berkembang dalam usaha peduli terhadap lingkungannya.

Kinerja lingkungan perusahaan diukur melalui PROPER dengan menggunakan warna mulai dari yang terbaik emas, hijau, biru, merah, hingga yang terburuk hitam. PROPER diumumkan kepada masyarakat secara rutin selama satu tahun sekali, agar masyarakat dapat mengetahui tingkat penataan pengelolaan lingkungan pada perusahaan dengan hanya melihat warna yang ada. Berikut ini adalah keterangan warna dalam peringkat PROPER berdasarkan Peraturan Kementerian Lingkungan Hidup Nomor 5 Tahun 2011:

1.

$$
\text { Emas }
$$

Diberikan kepada penanggung jawab usaha dan/atau kegiatan yang telah secara konsisten menunjukkan keunggulan lingkungan (environmental excellency) dalam proses produksi dan/atau jasa, melaksanakan bisnis yang beretika dan bertanggung jawab terhadap masyarakat.

2. Hijau : Diberikan kepada penanggung jawab usaha dan/atau kegiatan yang telah melakukan pengelolaan lingkungan lebih dari yang di persyaratkan dalam peraturan (beyond compliance) melalui pelaksanaan sistem pengelolaan lingkungan, pemanfaatan sumber daya secara efisien melalui upaya 4R (Reduce, Reuse, Recycle dan Recovery) dan melakukan upaya tanggung jawab sosial (CSR/comdev) dengan baik.

3.

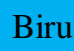

Diberikan kepada penanggung jawab usaha dan/atau kegiatan yang telah melakukan upaya 
pengelolaan lingkungan yang di persyaratkan sesuai dengan ketentuan dan atau peraturan perundangundangan.

4. Merah : Diberikan kepada penanggung jawab usaha dan/atau kegiatan yang telah melakukan upaya pengelolaan lingkungan hidup tetapi belum sesuai dengan persyaratan sebagaimana diatur dalam peraturan perundang-undangan.

5.

\section{Hitam}

:- Diberikan kepada penanggung jawab usaha dan/atau kegiatan yang sengaja melakukan perbuatan atau melakukan kelalaian yang mengakibatkan pencemaran dan/atau kerusakan lingkungan serta pelanggaran terhadap peraturan perundang-undangan atau tidak melaksanakan sanksi administrasi.

Sejumlah riset melaporkan jika perusahaan perduli dengan isu-isu tanggung jawab sosial dan lingkungan dalam jangka panjang perusahaan akan memperoleh dampak positif. Perusahaan yang melaksanakan CSR maka citra perusahaan akan semakin baik sehingga loyalitas konsumen dan para stakeholder semakin tinggi, sebaliknya jika tingkat pengungkapan CSR ini rendah maka akan menghambat perusahaan dalam hal memperoleh kepercayaan dari investor. CSR menjadi salah satu hal yang diperhatikan investor ketika akan berinvestasi di sebuah perusahaan (Fajriana, 2016).

Isu lingkungan yang paling banyak mendapat perhatian dan paling sering terjadi yaitu pencemaran sungai oleh bahan kimia berbahaya dari sisa pengelolaan hasil industri, terlebih bagi perusahaan yang bergerak di bidang manufaktur. Proses produksi dari perusahaan manufaktur tidak bisa dipungkiri pasti akan meninggalkan limbah, jika limbah tersebut tidak diolah dengan sedemikian rupa maka kontribusi perusahaan pada lingkungan adalah melakukan pencemaran.

Perusahaan dengan adanya informasi environmental performance yang berkualitas baik dan diungkapkannya environmental disclosure dalam laporan tahunan dapat memberikan gambaran tentang kinerja perusahaan secara komprehensif. Gambaran tersebut dapat berupa informasi keuangan maupun informasi non keuangan yang perlu diketahui oleh para pemegang saham, calon investor, pemerintah, atau bahkan masyarakat. Pengungkapan informasi yang dilakukan perusahaan di dalam laporan tahunan akan menjadi salah satu bahan pertimbangan bagi investor untuk melakukan investasi pada perusahaan yang bersangkutan. Keputusan investor untuk menanamkan modalnya didorong karena adanya harapan untuk memperoleh return atas investasi yang dilakukan, semakin baik kinerja suatu perusahaan maka akan semakin menarik minat investor karena keuntungan atau return yang diharapkan juga akan semakin besar. Perusahaan harus berusaha menunjukkan kinerja terbaiknya agar keputusan yang diambil investor dapat menguntungkan perusahaan. Salah satu caranya adalah dengan melakukan kegiatan sosial dan aktivitas lingkungan sebagai wujud tanggung jawab perusahaan terhadap lingkungan di sekitarnya.

Eipstein dan Freedman dalam Octavia (2012) menemukan bahwa investor perorangan tertarik terhadap informasi sosial berupa keamanan dan kualitas produk serta aktivitas lingkungan yang dilaporkan dalam laporan tahunan perusahaan. Perusahaan yang memiliki kinerja dan pengungkapan lingkungan yang baik, akan mendapat respon positif dari investor berupa ketertarikan terhadap pembelian saham perusahaan dan hal tersebut akan membuat permintaan saham perusahaan naik dan fluktuasi harga saham meningkat.

Hal lain yang mempengaruhi return saham adalah profitabilitas perusahaan dan salah satu rasio keuangan yang sering digunakan untuk memprediksi return saham adalah Return On Asset (selanjutnya disebut ROA). Profitabilitas merupakan indikator kinerja yang dilakukan manajemen dalam mengelola kekayaan perusahaan. ROA merupakan salah satu rasio profitabilitas, dimana rasio ini mengukur seberapa besar kemampuan perusahaan memperoleh laba atas sejumlah aktiva yang digunakan dalam perusahaan (Amini, 2016). Setiap perusahaan berusaha agar nilai dari ROA mereka tinggi. Semakin besar nilai dari ROA berarti semakin baik perusahaan menggunakan assetnya untuk mendapat laba, dengan meningkatnya nilai 
ROA maka profitabilitas dari perusahaan semakin meningkat (Arista dalam Amini, 2016). Hal ini dapat membuat investor menjadi tertarik untuk membeli saham perusahaan sehingga berdampak pada harga saham yang semakin meningkat dan diikuti dengan tingkat pengembalian return saham yang tinggi.

\section{KAJIAN LITERATUR}

\section{Signaling Theory}

Teori sinyal merupakan salah satu teori utama yang dapat digunakan untuk memahami pengaruh kinerja lingkungan terhadap return saham. Berdasarkan teori sinyal bahwa setiap tindakan mencerminkan informasi. Perusahaan yang menghasilkan kinerja berkualitas baik diharapkan menyajikan informasi secara transparan, khususnya informasi kegiatan lingkungan perusahaan. Penyajian pelaporan informasi aktivitas lingkungan sebagai salah satu cara untuk memberikan sinyal positif kepada para investor agar mau menginvestasikan sahamnya pada perusahaan yang memiliki kinerja lingkungan yang berkualitas baik (Purwaningsih, 2017).

Perusahaan dalam mengelola kegiatan lingkungannya harus dapat berkomitmen dan perhatian, sehingga perusahaan dapat menciptakan kinerja lingkungan yang berkualitas baik. Seluruh kegiatan penataan lingkungan perusahaan tercantum dalam PROPER. Reaksi investor terhadap pengumuman PROPER dapat menciptakan sinyal positif bahwa perusahaan telah menerapkan sistem manajemen lingkungan yang baik. Perusahaan sudah selayaknya bersedia untuk menyajikan informasi kegiatan lingkungannya sesuai standar lingkungan yang berlaku, agar dapat meningkatkan return saham.

Teori Sinyal menekankan kepada pentingnya suatu informasi yang diterbitkan oleh perusahaan terhadap keputusan investor yang merupakan pihak di luar perusahaan. Informasi merupakan unsur penting bagi investor dan pelaku bisnis karena informasi pada hakekatnya menyajikan keterangan, catatan atau gambaran baik untuk keadaan masa lalu, saat ini maupun keadaan masa yang akan datang. Informasi yang lengkap, relevan, akurat dan tepat waktu sangat diperlukan oleh investor di pasar modal sebagai alat analisis untuk mengambil keputusan investasi.
Berdasarkan teori sinyal, environmental performance perusahaan, environmental disclosure dan profitabilitas memberikan informasi kepada investor tentang prospek return masa depan. Sinyal yang dikirimkan dapat berupa perusahaan memiliki prospek yang baik (good news) yang diberikan oleh pihak manajemen kepada publik. Sinyal good news menyatakan bahwa perusahaan memiliki prospek bagus di masa depan dan memastikan terciptanya keberlanjutan pembangunan atau sebaliknya prospek yang buruk (bad news). Perusahaan dengan kinerja lingkungan yang baik dan pengungkapan lingkungan yang tegas berharap dapat meningkatkan reputasi dan nilai perusahaan melalui peningkatan return saham.

\section{Return Saham}

Return saham adalah tingkat pengembalian yang diperoleh investor baik keuntungan atau kerugian dari aktivitas investasi dan dapat menjadikan bahan pertimbangan dalam membeli serta mempertahankan saham (Rama, 2018). Return yang diterima oleh investor di pasar modal dibedakan menjadi dua jenis yaitu current income (pendapatan lancar) dan capital gain/capital loss (keuntungan selisih harga). Current income adalah keuntungan yang didapat melalui pembayaran yang bersifat periodik seperti dividen. Keuntungan ini biasanya diterima dalam bentuk kas atau setara kas sehingga dapat diuangkan secara cepat. Dividen saham yaitu dibayarkan dalam bentuk saham yang bisa dikonversi menjadi uang kas dengan cara menjual saham yang diterimanya, sedangkan capital gain (loss) merupakan selisih laba (rugi) yang dialami oleh pemegang saham karena harga saham sekarang relatif lebih tinggi (rendah) dibandingkan harga saham sebelumnya. Capital gain terjadi jika harga saham saat ini (Pt) lebih tinggi dari harga saham periode sebelumnya (Pt-1) maka pemegang saham mengalami capital gain, jika yang terjadi sebaliknya maka pemegang saham akan mengalami capital loss (Irwansyah, Saryadi dan Wijayanto, 2014). Return saham yang digunakan dalam penelitian ini adalah capital gain (loss), karena capital gain (loss) dapat menggambarkan respon pasar terhadap kondisi perusahaan. Capital gain (loss) merupakan selisih laba (rugi) yang dialami oleh pemegang saham karena harga saham sekarang relatif 
lebih tinggi (rendah) dibandingkan harga saham sebelumnya.

\section{Kinerja Lingkungan (Environmental Performance)}

Environmental Performance atau kinerja lingkungan merupakan kinerja suatu perusahaan yang peduli terhadap lingkungan sekitar. Kinerja lingkungan yang baik merupakan cerminan dari kegiatan penjagaan lingkungan yang dilakukan oleh perusahaan. Hal tersebut diapresiasi oleh pemerintah dengan diciptakannya Program Penilaian Peringkat Kinerja Perusahaan (PROPER) yang dikelola oleh Kementerian Lingkungan Hidup (KLH).

Perusahaan yang memiliki environmental performance yang baik merupakan good news bagi investor dan calon investor sehingga akan direspon secara positif oleh investor melalui fluktuasi harga saham perusahaan (Ihsan, 2017)

Berdasarkan UU No. 4 tahun 1982 mengenai pokok-pokok Pengelolaan Lingkungan Hidup pasal 1 yaitu lingkungan hidup adalah kesatuan ruangan dengan semua benda, daya, keadaan, dan makhluk hidup. Termasuk didalamnya manusia dan perilakunya yang mempengaruhi kelangsungan perikehidupan dan kesejahteraan manusia serta makhluk hidup lainnya.

\section{Pengungkapan Lingkungan (Environmental Disclosure)}

Pengungkapan lingkungan menurut Kementerian Lingkungan Hidup adalah suatu istilah yang sering digunakan oleh suatu instansi perusahaan maupun organisasi. Pengungkapan lingkungan digunakan untuk mengungkapkan data yang berhubungan dengan kinerja lingkungan, risiko lingkungan, dampak lingkungan, dan biaya lingkungan kepada pihak yang memiliki kepentingan yang bertujuan untuk meningkatkan hubungan dengan institusi atau organisasi. Investor akan lebih memilih perusahaan yang peka terhadap lingkungan sekitar.

Kelestarian lingkungan baik secara langsung maupun tidak langsung, berhubungan dengan kegiatan perusahaan. Pengungkapan
Lingkungan juga dapat diartikan sebagai suatu proses yang digunakan oleh perusahaan untuk mengungkapkan informasi yang berkaitan dengan kegiatan perusahaan dan pengaruhnya terhadap lingkungan kepada publik.

Hasil Penelitian Rizkan, Islahuddin dan Nadirsyah (2016) menyatakan bahwa pengungkapan aspek lingkungan telah menjadi suatu hal yang sensitif dan dapat memberikan pengaruh terhadap pencapaian financial performance suatu perusahaan.

\section{Profitabilitas}

Profitabilitas dalam penelitian ini sejalan dengan pendapat Machfoedz dalam Erari (2014), yaitu profitabilitas dapat diproksikan dengan Return On Asset (ROA). ROA yang meningkat akan meningkatkan return saham. Perusahaan dengan ROA yang besar akan menarik minat para investor untuk menanamkan dananya kedalam perusahaan.

Kemampuan perusahaan untuk menghasilkan laba dalam kegiatan operasinya merupakan fokus utama dalam penilaian prestasi perusahaan, karena laba perusahaan selain merupakan indikator kemampuan perusahaan memenuhi kewajiban bagi para penyandang dananya juga merupakan elemen dalam penciptaan nilai perusahaan yang menunjukkan prospek perusahaan di masa yang akan datang (Rusmita, 2016)

Return On Asset (ROA) adalah rasio yang digunakan untuk mengukur tingkat kemampuan perusahaan untuk menghasilkan laba dalam kegiatan operasional (Profitabilitas). Laba merupakan fokus utama dalam penilaian prestasi perusahaan (analisis fundamental perusahaan) karena laba perusahaan selain merupakan indikator kemampuan perusahaan memenuhi kewajiban bagi para penyandang dananya juga merupakan elemen dalam penciptaan nilai perusahaan yang menunjukkan prospek perusahaan di masa yang akan datang.

\section{Kerangka Pemikiran dan Pengembangan Hipotesis}

Berikut ini disajikan kerangka pemikiran yang dituangkan dalam model penelitian pada gambar sebagai berikut: 


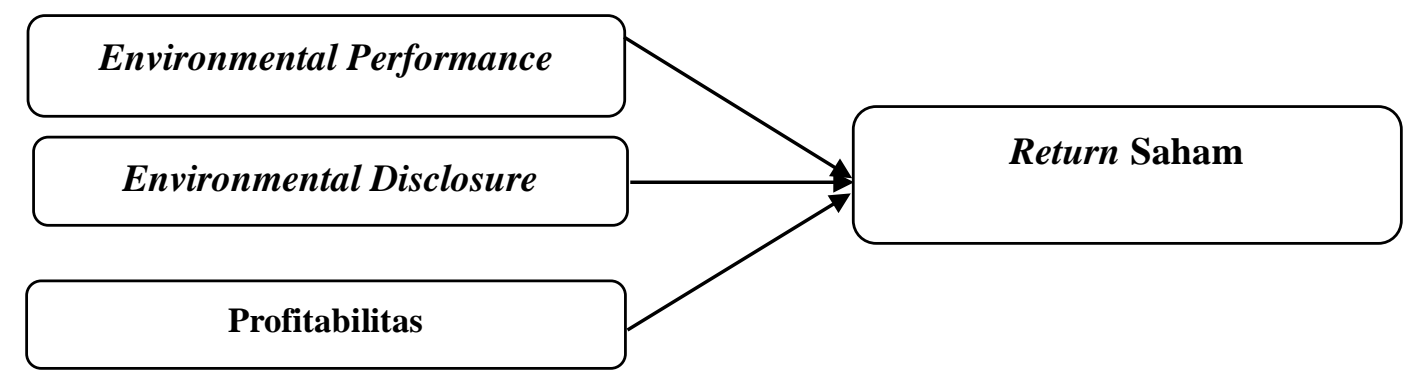

Gambar 1. Kerangka Pemikiran

\section{METODE}

Populasi dalam penelitian ini adalah seluruh perusahaan manufaktur yang memperoleh peringkat PROPER (Program
Penilaian Peringkat Kinerja Perusahaan) dan terdaftar di BEI (Bursa Efek Indonesia) tahun 2015-2018. Sampel dipilih menggunakan metode purposive sampling dan diperoleh sebanyak 37 perusahaan sampel.

Tabel 1. Penyaringan Populasi Dan Sampel Penelitian

\begin{tabular}{lc}
\hline \multicolumn{1}{c}{ Keterangan } & Jumlah \\
\hline Perusahaan manufaktur yang memperoleh peringkat PROPER yang terdaftar di & 42 \\
Bursa Efek Indonesia pada tahun 2015-2018 & $(5)$ \\
Perusahaan manufaktur yang tidak memperoleh peringkat PROPER yang terdaftar di & 37 \\
Bursa Efek Indonesia secara berturut-turut pada tahun 2015-2018 & 37 \\
Jumlah sampel yang sesuai dengan kriteria & \\
\hline
\end{tabular}

Jenis data yang digunakan dalam penelitian ini adalah data kuantitatif, yaitu data yang diukur dalam skala numerik (angka). Penelitian kuantitatif yang dilakukan bertujuan untuk menguji apakah terdapat pengaruh antara Kinerja Lingkungan (Environmental Performance), Pengungkapan Lingkungan (Environmental Disclosure) dan Profitabilitas terhadap Tingkat Pengembalian (Return) Saham pada perusahaan-perusahaan manufaktur yang mengikuti PROPER dan terdaftar di Bursa Efek Indonesia periode 20152018. Penelitian ini menggunakan tiga variabel penelitian yaitu variabel return saham, kinerja lingkungan (environmental disclosure), pengungkapan lingkungan (environmental disclosure), dan profitabilitas.

\section{Definisi Operasional Variabel}

Kinerja lingkungan perusahaan diukur dari prestasi perusahaan dalam mengikuti PROPER. Sistem peringkat kinerja PROPER meliputi pemeringkatan perusahaan dalam lima warna yang diberi skor nilai secara berkelanjutan. Rating penilaian peringkat PROPER seperti Tabel 2 berikut:

Tabel 2. Rating Penilaian Peringkat Proper

\begin{tabular}{cc}
\hline Indikator & Nilai \\
\hline Peringkat Warna Emas & 5 \\
Peringkat Warna Hijau & 4 \\
Peringkat Warna Biru & 3 \\
Peringkat Warna Merah & 2 \\
Peringkat Warna Hitam & 1 \\
\hline Sumber: Kementerian Lingkungan Hidup
\end{tabular}

Pengungkapan Lingkungan

(Environmental Disclosure) sebagai suatu proses yang digunakan oleh perusahaan untuk mengungkapkan informasi yang berkaitan dengan kegiatan perusahaan dan pengaruhnya terhadap lingkungan kepada publik. Metode skoring terhadap Indeks Pengungkapan
Lingkungan (environmental disclosure index) digunakan untuk mengukur sejauh mana pengungkapan lingkungan yang telah dilakukan oleh perusahaan dalam laporan tahunan. Indeks pengungkapan lingkungan yang dikembangkan oleh Hossain, et al (2006) digunakan dalam penelitian ini sebanyak 18 
kriteria pengungkapan lingkungan yang seharusnya diungkapkan oleh perusahaan terkait dengan kinerja lingkungannya.

Tabel 3. Indeks Pengungkapan Lingkungan (Environmental Disclosure Index)

\begin{tabular}{|c|c|c|}
\hline No. & Informasi Lingkungan & Skor \\
\hline 1 & $\begin{array}{l}\text { Pengeluaran masa lalu dan saat ini untuk peralatan dan fasilitas pengendalian } \\
\text { polusi (Past and current expenditure for pollution control equipment and facilities) }\end{array}$ & 1 \\
\hline 2 & $\begin{array}{l}\text { Biaya operasi masa lalu dan saat ini dari peralatan dan fasilitas pengendalian polusi } \\
\text { (Past and current operating costs of pollution control equipment and facilities) }\end{array}$ & 1 \\
\hline 3 & $\begin{array}{l}\text { Perkiraan pengeluaran di masa depan untuk peralatan dan fasilitas pengendalian } \\
\text { polusi (Future estimates of expenditures for pollution control equipment and } \\
\text { facilities) }\end{array}$ & 1 \\
\hline 4 & $\begin{array}{l}\text { Perkiraan biaya operasi untuk peralatan dan fasilitas pengendalian polusi di masa } \\
\text { depan (Future estimates of operating costs for pollution control equipment and } \\
\text { facilities) }\end{array}$ & 1 \\
\hline 5 & $\begin{array}{l}\text { Pendanaan untuk peralatan atau fasilitas pengendalian polusi (Financing for } \\
\text { pollution control equipment or facilities) }\end{array}$ & 1 \\
\hline 6 & Informasi emisi udara (Air emission information) & 1 \\
\hline 7 & Informasi pembuangan air (Water discharge information) & 1 \\
\hline 8 & Informasi pembuangan limbah padat (Solid waste disposal information) & 1 \\
\hline 9 & $\begin{array}{l}\text { Kebijakan lingkungan atau kepedulian perusahaan terhadap lingkungan } \\
\text { (Environmental policies or company concern for the environment) }\end{array}$ & 1 \\
\hline 10 & Konservasi sumber daya alam (Conservation of natural resources) & 1 \\
\hline 11 & Pabrik daur ulang produk limbah (Recycling plant of waste products) & 1 \\
\hline 12 & Instalasi pabrik pengolahan limbah (Installation of effluent treatment plant) & 1 \\
\hline 13 & Kampanye anti-sampah dan konservasi (Anti-litter and conservation campaign) & 1 \\
\hline 14 & Program reklamasi dan hutan (Land reclamation and forestation programmes) & 1 \\
\hline 15 & Pengendalian pencemaran proses industry (Pollution control of industrial process) & 1 \\
\hline 16 & $\begin{array}{l}\text { Penelitian tentang metode produksi baru untuk mengurangi pencemaran lingkungan } \\
\text { (Research on new methods of production to reduce environmental pollution) }\end{array}$ & 1 \\
\hline 17 & Konservasi bahan baku (Raw materials conservation) & 1 \\
\hline 18 & $\begin{array}{l}\text { Dukungan untuk tindakan publik atau pribadi yang dirancang untuk melindungi } \\
\text { lingkungan (Support for public or private action designed to protect the } \\
\text { environment) }\end{array}$ & 1 \\
\hline
\end{tabular}

Sumber: Hossain et al. (2006)

Skor akhir Environmental Disclosure menurut Octavia (2012) dirumuskan sebagai berikut:

$$
\text { Skor Akhir ED }=\frac{\text { Total pengungkapan lingkungan yang dilakukan }}{\text { Total pengungkapan lingkungan yang seharusnya dilakukan }}
$$

Profitabilitas dalam penelitian ini diproksikan dengan Return On Asset. ROA digunakan untuk mengukur kemampuan perusahaan atas keseluruhan dana yang ditanamkan dalam aktivitas operasi perusahaan dengan tujuan untuk menghasilkan laba dengan memanfaatkan aktiva yang dimilikinya. Semakin besar rasio ini maka smakin baik dan hal ini berarti bahwa aktiva lebih cepat berputar dan meraih laba bersih. ROA merupakan rasio antara laba bersih sesudah pajak terhadap total aset. Menurut Putri dan Djoko (2012), ROA dirumuskan sebagai berikut:

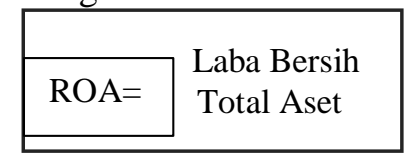

Return Saham merupakan salah satu faktor yang memotivasi investor untuk berinvestasi dan juga merupakan imbalan atas keberanian investor menanggung resiko atas berinvestasi yang dilakukannya. Pada penelitian ini return saham yang akan diteliti adalah dengan melihat 
perubahan nilai harga saham pada periode $t+1$ dengan periode t. Menurut Hartono (2015) Return saham dirumuskan sebagai berikut:

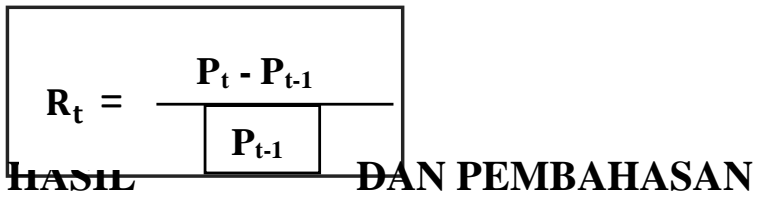

Berdasarkan hasil pada Tabel 4, jumlah data yang diolah sebanyak 104 observasi selama tahun 2015-2018 dengan variabel dependen (Y) yaitu Return Saham dan variabel
Keterangan:

Rt = Return saham pada periode ke-t

$\mathrm{Pt} \quad=$ Harga saham periode pengamatan

$\mathrm{Pt}^{-1} \quad$ = Harga saham periode sebelum

pengamatan

independen yaitu Kinerja Lingkungan $\left(\mathrm{X}_{1}\right)$, Pengungkapan Lingkungan $\left(\mathrm{X}_{2}\right)$, dan Profitabilitas $\left(\mathrm{X}_{3}\right)$ dengan hasil output untuk uji statistik deskriptif sebagai berikut:

Tabel 4. Hasil Uji Statistik Deskriptif

\begin{tabular}{lrrrrr}
\hline \multicolumn{7}{c}{ Descriptive Statistics } \\
\hline N & \multicolumn{1}{c}{ Minimum } & \multicolumn{1}{c}{ Maximum } & Mean & \multicolumn{1}{c}{ Std. Deviation } \\
\hline RET & 104 & -.987 & 1.000 & .06954 & .439549 \\
EP & 104 & 2 & 4 & 3.11 & .481 \\
ED & 104 & .167 & .444 & .32420 & .091818 \\
ROA & 104 & -.160 & 1.102 & .11843 & .152657 \\
Valid N (listwise) & 104 & & & & \\
\hline
\end{tabular}

Sumber: Data diolah

\section{Return Saham}

Teknik analisis yang digunakan dalam return saham pada penelitian ini yaitu dengan melihat perubahan harga saham pada akhir periode pengamatan dengan akhir periode setelah tahun pengamatan. Nilai return saham pada Tabel 6 memiliki nilai terendah (minimum) sebesar -0,987 pada perusahaan Citra Tubindo Tbk pada tahun 2015. Angka minus dari nilai minimum tersebut dikarenakan ada beberapa perusahaan sampel yang memiliki return saham negatif selama tiga tahun berturut-turut selama periode penelitian, diantaranya ADES, CTBN, MAIN pada tahun 2015-2017 dan IKBI pada tahun 2016-2018. Nilai return saham yang negatif tersebut berarti setiap return pasar naik $1 \%$ akan mengakibatkan return sekuritas turun sebesar 0,987\%. Nilai tertinggi (maximum) sebesar 1,000 pada perusahaan Wilmar Cahaya Indonesia Tbk pada tahun 2016, yang artinya setiap perubahan return pasar $1 \%$ akan mengakibatkan perubahan sekuritas dengan arah yang sama sebesar $1,000 \%$. Nilai rata-rata (mean) sebesar 0,069, hal ini berarti bahwa selama periode penelitian rata-rata setiap perubahan return sekuritas sebesar 0,069\%. Standar deviasi return saham sebesar 0,439, hal ini berarti bahwa selama periode penelitian ukuran penyebaran dari variabel return saham sebesar 0,439.

\section{Kinerja Lingkungan (Environmental Performance)}

Variabel independen yang pertama $\left(\mathrm{X}_{1}\right)$ adalah Kinerja Lingkungan (Environmental Performance) yang diproksikan berdasarkan pada peringkat kinerja lingkungan yang diperoleh perusahaan dalam PROPER. Variabel ini memiliki skor terendah (minimum) sebesar 2 yang artinya terdapat perusahaan sampel berada pada peringkat merah, diantaranya TFCO pada tahun 2015, IKBI pada tahun 2016, 2017 dan 2018, MBTO pada tahun 2018, UNIC pada tahun 2015 dan KBLM pada tahun 2015. Skor tertinggi (maximum) sebesar 4 yang artinya terdapat perusahaan sampel berada pada peringkat hijau, diantaranya INDF pada tahun 2016, 2017, MYOR pada tahun 2015, UNVR pada tahun 2015-2018, INTP pada tahun 2015, 2017, HMSP pada tahun 2017, 2018, ICBP pada tahun 2015, 2017, 2018 dan SMGR pada tahun 2015-2018. Nilai ratarata (mean) sebesar 3,11, jika nilai rata-rata sampel dikonversi berdasarkan kategori PROPER nilai tersebut berada pada peringkat biru, artinya rata-rata perusahaan sampel memiliki kinerja lingkungan yang cukup baik.

\section{Pengungkapan Lingkungan (Environmental Disclosure)}

Variabel independen yang kedua $\left(\mathrm{X}_{2}\right)$ adalah Pengungkapan Lingkungan yang diproksikan berdasarkan pada indeks 
pengungkapan lingkungan dalam penelitian Hossain, et al (2006) yang terdiri dari 18 item pernyataan pengungkapan lingkungan. Variabel ini memiliki nilai terendah (minimum) sebesar 0,167 pada perusahaan Unggul Indah Cahaya Tbk pada tahun 2015 sebesar 16,7\% atau rata-rata 3 item yang diungkapkan setiap tahunnya. Nilai tertinggi (maximum) sebesar 0,444 pada perusahaan Unilever Indonesia Tbk pada tahun 2015 dengan nilai persentase 44,4\%, atau rata-rata 8 item yang diungkapkan setiap tahunnya. Nilai rata-rata (mean) sebesar 0,324 atau $32,4 \%$, yang artinya rata-rata setiap perusahaan mengungkapkan 6 item dari 18 item yang ada.

\section{Profitabilitas}

Variabel independen yang ketiga $\left(\mathrm{X}_{3}\right)$ adalah profitabilitas yang diproksikan dengan return on asset (ROA). Variabel ini memiliki nilai terendah (minimum) sebesar $-0,160$ pada perusahaan Martina Berto Tbk pada tahun 2018. Nilai tertinggi (maximum) sebesar 1,102 pada perusahaan Merck Tbk pada tahun 2018. Nilai rata-rata (mean) sebesar 0,118 , hal ini berarti bahwa setiap Rp 1 aset perusahaan dapat menghasilkan Rp 0,118 laba. Standar deviasi profitabilitas sebesar 0,153 , berarti bahwa selama periode penelitian ukuran penyebaran dari variabel profitabilitas sebesar 0,153.

Uji Normalitas. Hasil uji normalitas pada penelitian ini dapat dilihat di Tabel 5, bahwa pengujian normalitas data pada penelitian ini menunjukkan nilai signifikansi sebesar 0,200 yang artinya data dalam penelitian ini terdistribusi dengan normal.

Tabel 5. Hasil Uji Normalitas

One-Sample Kolmogorov-Smirnov Test

\begin{tabular}{llr}
\hline & & Unstandardized Residual \\
\hline N & & 104 \\
Normal Parameters $^{\text {a,b }}$ & Mean & .0000000 \\
& Std. Deviation & .39429325 \\
Most Extreme & Absolute & .067 \\
Differences & Positive & .067 \\
& Negative & -.065 \\
Test Statistic & & .067 \\
Asymp. Sig. (2-tailed) & & $.200^{\text {c.d }}$ \\
a. Test distribution is Normal. & \\
b. Calculated from data. & & \\
c. Lilliefors Significance Correction. &
\end{tabular}

Sumber: Data diolah

Uji Multikolinearitas. Tabel 6, menunjukkan bahwa seluruh variabel bebas dalam penelitian ini terbebas dari multikolinearitas, karena seluruh variabel bebas memiliki nilai tolerance diatas 0,10 dan nilai VIF dibawah 10 , sehingga model regresi layak digunakan.

\begin{tabular}{|c|c|c|c|}
\hline \multicolumn{4}{|c|}{ Coefficients $^{\mathrm{a}}$} \\
\hline & & \multicolumn{2}{|c|}{ Collinearity Statistics } \\
\hline \multicolumn{2}{|c|}{ Model } & Tolerance & VIF \\
\hline \multirow[t]{4}{*}{1} & (Constant) & & \\
\hline & EP & .976 & 1.025 \\
\hline & ED & .923 & 1.084 \\
\hline & ROA & .934 & 1.071 \\
\hline
\end{tabular}

Sumber: Data diolah

Uji Autokorelasi. Berdasarkan uji autokorelasi pada Tabel 7 terlihat bahwa nilai Durbin Watson $(\mathrm{d})=2,015$, jumlah obsevasi $(\mathrm{n})=104$, dan jumlah variabel bebas $(\mathrm{k})=3$. Tabel Durbin
Watson dengan tingkat signifikan $(\alpha=0,05)$, diperoleh nilai batas atas $(\mathrm{dU})=1,7402$ dan nilai batas bawah $(\mathrm{dL})=1,6217$. Nilai Durbin Watson (d) sebesar 2,015 lebih besar dari nilai 
(dU) 1,7402 dan lebih kecil dari (4-dU) 4 $1,7402=2,2598$, artinya bahwa nilai Durbin Watson berada pada daerah tidak ada autokorelasi positif atau negatif, sehingga dapat diartikan bahwa dalam penelitian ini tidak terjadi autokorelasi.

Tabel 7. Hasil Uji Autokorelasi Model Summary ${ }^{b}$

\begin{tabular}{|c|c|c|c|c|c|}
\hline \multicolumn{6}{|c|}{ Model Summary ${ }^{\mathbf{b}}$} \\
\hline Model & $\mathbf{R}$ & R Square & Adjusted R Square & $\begin{array}{l}\text { Std. Error of the } \\
\text { Estimate }\end{array}$ & Durbin-Watson \\
\hline 1 & $.732^{\mathrm{a}}$ & .536 & .503 & .400164 & 2.015 \\
\hline $\begin{array}{l}\text { a. Predic } \\
\text { b. Depen }\end{array}$ & $\begin{array}{l}\text { (Cons } \\
\text { Varial }\end{array}$ & $\begin{array}{l}\text { ant), ROA, } \\
\text { le: RET }\end{array}$ & $\mathrm{D}, \mathrm{EP}$ & & \\
\hline
\end{tabular}

b. Dependent Variable: RET

Sumber: Data diolah

Uji Heteroskedastisitas. Gambar 2, menunjukkan sebaran titik-titik pada gambar tersebut berada di atas dan di bawah angka nol (0) sumbu Y dan menyebar di sisi kiri dan sisi kanan sumbu $\mathrm{X}$ yang artinya, titik sebaran tidak membentuk pola tertentu, sehingga tidak terjadinya heteroskedastisitas pada model regresi yang digunakan pada penelitian ini

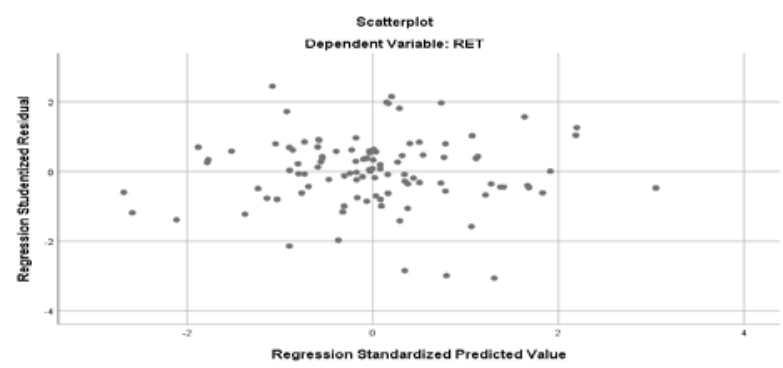

Gambar 2. Hasil Uji Heteroskedastisitas

Sumber: Data diolah

\section{Model Regresi Linear Berganda}

Analisis regresi linear berganda dilakukan untuk mengetahui pengaruh variabel bebas yaitu Kinerja Lingkungan (Environmental Performance), Pengungkapan
Lingkungan (Environmental Disclosure) dan profitabilitas terhadap variabel terikat yaitu Return Saham. Hasil uji analisis regresi linear berganda pada penelitian ini dapat dilihat pada Tabel 7 sebagai berikut:

Tabel 8. Hasil Uji Analisis Regresi Linear Berganda

\begin{tabular}{|c|c|c|c|c|c|c|}
\hline \multicolumn{7}{|c|}{ Coefficients $^{\mathrm{a}}$} \\
\hline & \multirow[t]{2}{*}{ Model } & \multicolumn{2}{|c|}{$\begin{array}{c}\text { Unstandardized } \\
\text { Coefficients } \\
\end{array}$} & \multirow{2}{*}{$\begin{array}{c}\begin{array}{c}\text { Standardized } \\
\text { Coefficients }\end{array} \\
\text { Beta } \\
\end{array}$} & \multirow[t]{2}{*}{$\mathbf{T}$} & \multirow[t]{2}{*}{ Sig. } \\
\hline & & B & Std. Error & & & \\
\hline \multirow[t]{4}{*}{1} & (Constant) & -.872 & .270 & & -3.232 & .002 \\
\hline & EP & .183 & .078 & .212 & 2.337 & .021 \\
\hline & ED & 1.000 & .447 & .209 & 2.236 & .028 \\
\hline & ROA & .492 & .188 & .243 & 2.613 & .010 \\
\hline
\end{tabular}

a. Dependent Variable: RET (Y)

Sumber: Data diolah

Berdasarkan hasil pengujian pada Tabel 8 dengan metode regresi linear berganda untuk menguji pengaruh variabel-variabel independen terhadap variabel dependen, maka dapat disusun persamaan sebagai berikut:

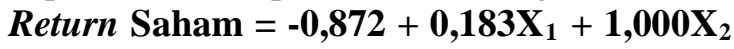
$+0,492 X_{3}$
Berdasarkan hasil persamaan regresi linear berganda tersebut dapat disimpulkan bahwa:

a. Nilai konstanta untuk variabel Return Saham adalah $-0,872$ yang berarti apabila environmental performance $\left(\mathrm{X}_{1}\right)$ dan environmental disclosure $\left(\mathrm{X}_{2}\right)$ bernilai nol 
(0) maka nilai return saham (Y) sebesar 0,872 .

b. Nilai koefisien regresi variabel environmental performance adalah 0,183 yang berarti apabila environmental performance mengalami peningkatan sebesar 1\% maka return saham mengalami kenaikan sebesar 0,183 dengan asumsi variabel lain konstan.

c. Nilai koefisien regresi variabel environmental disclosure adalah 1,000

\section{Uji Hipotesis}

Hasil pengujian hipotesis disajikan pada Tabel 9. yang berarti apabila environmental disclosure mengalami peningkatan sebesar $1 \%$ maka return saham mengalami kenaikan sebesar 1,000 dengan asumsi variabel lain konstan.

Nilai koefisien regresi variabel profitabilitas adalah 0,492 yang berarti apabila profitabilitas mengalami peningkatan sebesar $1 \%$ maka profitabilitas mengalami kenaikan sebesar 0,492 dengan asumsi variabel lain konstan.

Tabel 9. Hasil Uji t

\begin{tabular}{|c|c|c|c|c|c|c|}
\hline \multicolumn{7}{|c|}{ Coefficients $^{\mathrm{a}}$} \\
\hline & \multirow{2}{*}{ Model } & \multicolumn{2}{|c|}{ Unstandardized Coefficients } & \multirow{2}{*}{$\begin{array}{c}\begin{array}{c}\text { Standardized } \\
\text { Coefficients }\end{array} \\
\text { Beta } \\
\end{array}$} & \multirow{2}{*}{ t } & \multirow{2}{*}{ Sig. } \\
\hline & & B & Std. Error & & & \\
\hline \multirow[t]{4}{*}{1} & (Constant) & -.872 & .270 & & -3.232 & .002 \\
\hline & EP & .183 & .078 & 212 & 2.337 & .021 \\
\hline & ED & 1.000 & .447 & .209 & 2.236 & .028 \\
\hline & ROA & .492 & .188 & .243 & 2.613 & .010 \\
\hline
\end{tabular}

Sumber: Data diolah

\section{a. Environmental berpengaruh positif terhadap Return Saham}

Berdasarkan hasil pengujian hipotesis pada Tabel 8 yang telah dilakukan variabel $\mathrm{X}_{1}$ (EP) memiliki pengaruh yang siginifikan dengan menghasilkan nilai koefisien sebesar 0,183 dan nilai $t_{\text {hitung }}$ sebesar 2,337, serta dengan tingkat signifikansi sebesar 0,021 < 0,05 yang artinya tingkat signifikan pada variabel environmental performance lebih kecil atau dibawah 0,05, yang berarti variabel environmental performance berpengaruh signifikan terhadap return saham pada perusahaan manufaktur yang mengikuti PROPER dan terdaftar di Bursa Efek Indonesia (BEI) tahun 2015-2018 diterima.

\section{b. Environmental Disclosure berpengaruh positif terhadap Return Saham}

Berdasarkan hasil pengujian hipotesis pada Tabel 8, bahwa variabel $\mathrm{X}_{2}$ (ED) memiliki pengaruh yang siginifikan secara parsial dengan menghasilkan nilai koefisien sebesar 1,000 dan nilai $t_{\text {hitung }}$ sebesar 2,236, serta dengan tingkat signifikansi sebesar 0,028 < 0,05 yang artinya tingkat signifikan pada variabel environmental disclosure lebih kecil atau dibawah 0,05 , yang berarti variabel environmental disclosure berpengaruh signifikan terhadap return saham pada perusahaan manufaktur yang mengikuti PROPER dan terdaftar di Bursa Efek Indonesia (BEI) tahun 2015-2018 diterima.

\section{c. Profitabilitas berpengaruh positif terhadap Return Saham}

Berdasarkan hasil pengujian hipotesis pada Tabel 8, bahwa variabel $\mathrm{X}_{3}$ Profitabilitas memiliki pengaruh yang siginifikan secara parsial dengan menghasilkan nilai koefisien sebesar 0,492 dan nilai thitung sebesar 2,613, serta dengan tingkat signifikansi sebesar 0,010 $<0,05$ yang artinya tingkat signifikan pada variabel profitabilitas lebih kecil atau dibawah 0,05 , yang berarti variabel profitabilitas berpengaruh signifikan terhadap return saham pada perusahaan manufaktur yang mengikuti PROPER dan terdaftar di Bursa Efek Indonesia (BEI) tahun 2015-2018 diterima.

Berdasarkan Tabel 10 hasil uji F atau uji anova menghasilkan nilai $F$ hitung sebesar 8,091, jika dibandingkan dengan $\mathrm{F}$ tabel sebesar 2,69, maka nilai $\mathrm{F}$ hitung lebih besar dari $\mathrm{F}$ 
tabel dan dengan signifikansi 0,000 atau $<0,05$ yang artinya, secara simultan variabel independen kinerja lingkungan (environmental performance), pengungkapan lingkungan (environmental disclosure) dan profitabilitas berpengaruh terhadap variabel dependen return saham dan model regresi yang digunakan pada penelitian ini sudah tepat.

Tabel 10. Hasil Uji F

\begin{tabular}{llrrrrr}
\hline \multicolumn{7}{c}{ ANOVA $^{\mathbf{a}}$} \\
\hline & Model & Sum of Squares & Df & Mean Square & F & Sig. \\
\hline 1 & Regression & 3.887 & 3 & 1.296 & 8.091 & $.000^{\text {b }}$ \\
& Residual & 16.013 & 100 & .160 & & \\
& Total & 19.900 & 103 & & & \\
\hline
\end{tabular}

a. Dependent Variable: RET

b. Predictors: (Constant), ROA, ED, EP

Sumber: Data diolah

\section{Uji Koefisien Determinasi $\left(\mathbf{R}^{2}\right)$}

Tabel 11. Hasil Uji Koefisien Determinasi $\left(\mathbf{R}^{2}\right)$

\begin{tabular}{lcccr}
\hline \multicolumn{5}{c}{ Model Summary } \\
\hline Model & $\mathbf{R}$ & R Square & $\begin{array}{c}\text { Adjusted R } \\
\text { Square }\end{array}$ & $\begin{array}{c}\text { Std. Error of } \\
\text { the Estimate }\end{array}$ \\
\hline 1 & $.732^{\mathrm{a}}$ & .536 & .503 & .300164 \\
\hline a. Predictors: (Constant), ED, EP & & \\
\hline
\end{tabular}

Sumber: Data diolah

Tabel 11 menunjukkan bahwa nilai koefisien determinasi ( $\mathrm{R}$ square) sebesar 0,536 atau 53,6\% yang artinya, variabel-variabel independen (environmental performance, environmental disclosure dan profitabilitas) hanya mampu menjelaskan variabel dependen (return saham) sebesar 53,6\% dan sisanya sebesar 46,4\% dijelaskan oleh faktor-faktor lainnya diluar model regresi penelitian ini.

\section{SIMPULAN DAN SARAN}

\section{Simpulan}

Berdasarkan hasil penelitian ini dapat disimpulkan bahwa variabel independen mempunyai pengaruh signifikan terhadap variabel dependen pada perusahaan manufaktur yang mengikuti PROPER dan terdaftar di Bursa Efek Indonesia (BEI) tahun 2015-2018. Masyarakat sebagai calon investor cenderung tertarik terhadap informasi aktivitas sosial serta lingkungan yang dilaporkan dalam laporan yang diterbitkan perusahaan, dengan adanya kinerja lingkungan (environmental performance), pengungkapan lingkungan (environmental disclosure) dan profitabilitas yang baik maka investor akan memberikan respon positif berupa ketertarikan terhadap pembelian saham perusahaan Hal tersebut merupakan sinyal dari investor bahwa investor tertarik dengan isu-isu lingkungan dan menuntut perusahaan agar lebih memperhatikan kinerja lingkungannya dan melaksanakan pengungkapan lingkungan sebagaimana semestinya serta dapat mengelola total aktiva yang dimiliki perusahaan agar dapat memperoleh laba. Sinyal yang diberikan investor kepada perusahaan berupa permintaan saham perusahaan naik dan fluktuasi harga saham pun meningkat.

\section{Saran}

Berdasarkan dari hasil simpulan yang diperoleh maka penulis ingin memberikan saran bagi pihak-pihak yang berkepentingan yaitu sebagai berikut:

\section{Bagi Perusahaan}

Perusahaan sebaiknya semakin menyadari bahwa pentingnya penerapan kinerja lingkungan di dalam perusahaan, melaksanakan pengungkapan lingkungan dalam laporan tahunan perusahaan, serta dapat mengelola aktiva secara efektif dan efisien agar dapat meningkatkan laba perusahaan selain pengungkapan sosial dan ekonomi yang telah banyak dilakukan di dalam laporan tersebut

\section{Bagi Investor}


Bagi para investor diharapkan lebih cermat dalam menilai perusahaan sebelum memutuskan berinvestasi dan juga dalam menilai kualitas tata kelola kinerja lingkungan, pengungkapan lingkungan serta profitabilitas perusahaan berdasarkan pedoman yang berlaku.

\section{REFERENSI}

Amini, Fitria Indah. 2016. "Pengaruh Corporate Social Responsibility, Return On Asset dan Debt to Equity Ratio Terhadap Return Saham”. Skripsi. Universitas Negeri Yogyakarta. Yogyakarta.

Erari, Anita. (2014). Analisis Pengaruh Current Ratio, DER dan ROA terhadap Return Saham pada Perusahaan Pertambangan di Bursa Efek Indonesia. Jurnal Manajemen, Universitas Airlangga. Surabaya.

Fajriana, A. 2016. “Pengaruh Corporate Social Responsibility (CSR), Keputusan Investasi, dan Struktur Modal Terhadap Nilai Perusahaan Dengan Kepemilikan Manajerial Sebagai Variabel Pemoderasi”. Skripsi. Universitas Negeri Yogyakarta. Yogyakarta.

Ghozali, Imam. 2011. Aplikasi Analisis Multivariate dengan Program SPSS. Semarang: Badan Penerbit Universitas Diponegoro.

Hartono J. 2015. Teori Portofolio dan Analisis Investasi. Yogyakarta: BPFE.

Hastawati, R.R., dan Sarsiti. (2016). Pengaruh Kinerja Lingkungan dan Corporate Social Responsibility (CSR) terhadap Kinerja Keuangan Pada Perusahaan Manufaktur yang Terdaftar di Bursa Efek Indonesia Tahun 2011-2013. Jurnal Penelitian dan Kajian Ilmiah, 14(4), 4959.

Hossain, MA., Islam, KS., Andre, J. 2006. "Corporate Social and Environmental Disclosure in Developing Countries: Evidence from Bangladesh”. Asian Pasific on International Accounting Issues. Hawaii.

Ihsan, Muhammad. 2017. "Pengaruh Environmental Performance dan
Environmental Disclosure terhadap Economic Performance (Studi Empiris pada Perusahaan Manufaktur yang Terdaftar di Bursa Efek Indonesia Tahun 2014-2016)”. Skripsi. UIN Syarif Hidayatullah. Jakarta.

Irwansyah, Muhammad Ajib., Saryadi., Wijayanto Andi. (2014). Analisis Perbedaan Tingkat Harga Pasar Saham, Return Saham, Dan Volume Perdagangan Saham Perusahaan Sebelum Dan Sesudah Stock Split (Studi Kasus Pada Perusahaan Yang Melakukan Stock Split Periode 2008-2012). Jurnal Ilmu Administrasi Bisnis. Universitas Diponegoro. Semarang.

Mirza, Islahuddin dan Nadirsyah. (2017). "Pengaruh Environmental Performance dan Environmental Disclosure Terhadap Financial Performance Perusahaan Pertambangan dan Pemegang HPH/HPHTI yang Terdaftar di BEI”. Jurnal Magister Akuntansi. Universitas Syiah Kuala. Aceh.

Octavia, Itsna. 2012. "Pengaruh Pengungkapan Lingkungan Terhadap Nilai Perusahaan Dengan Profitabilitas Sebagai Variabel Moderasi”. Skripsi. Universitas Indonesia. Depok.

Purwaningsih, Eny. (2017). Pengaruh Implementasi Kinerja Lingkungan terhadap Return Saham yang Dimoderasi Corporate Governance. Jurnal Ilmiah. Universitas Esa Unggul. Jakarta.

Putri, Anggun Amelia dan Sampurno, R. Djoko. (2012). Analisis Pengaruh ROA, EPS, NPM, DER dan PBV Terhadap Return Saham. Jurnal Manajemen. Universitas Diponegoro. Semarang.

Rama, Bhre Reza. 2018. "Pengaruh Environmental Performance Dan Carbon Emission Dislosure Terhadap Return Saham”. Skripsi. Universitas Airlangga. Surabaya.

Rusmita, Sari. (2016). Pengaruh Return On Asset dan Corporate Social Responsibility Terhadap Return Saham. Jurnal Akuntansi. Universitas Tanjungpura. Kalimantan. 
JRAK, Volume 17, No.1 Februari 2021

www.menlhk.go.id (Diakses pada Juli 2019)

-----------www.idx.co.id (Diakses pada Juli 2019)

------------www.finance.yahoo.com (Diakses pada Juli 2019) 
